\title{
ENVIRONMENTAL SECURITY IN SOUTH-ASIA
}

\author{
Chandra Pandey
}

\begin{abstract}
The proposition that climate change will engender anxieties for international security has become profound in public discourse over two decades. This paper discusses the concerns of environmental security in South Asia. It examines different meanings of environmental security to explain how it is associated with national security of the states in the region. Three major factors of environmental security problems are considered. Firstly, how environmental change can affect human security. Secondly, how environmental change can turn into violent conflict and thirdly, how the combined impact of these two variables affect the developmental concerns and national security of the individual state in South Asia.
\end{abstract}

\section{Introduction}

Environmental security is one of a number of non-traditional security issues that has served to widen the concept of security. It deepens and broadens the concept of security in terms of resource conflicts and risks associated with environmental change. South Asia is becoming sensitive to a range of environmental security concerns, which have assumed considerable significance. Firstly, there is serious concern about the stripping forest cover in South Asia due to intense commercial 'logging' and subsistent farming. Secondly, there is emerging concern of the shrinking of the glacial cover in the Himalayas due to global warming. Thirdly, there are indications that the changing climate is significantly impacting upon the weather patterns resulting into food insecurity and water-borne diseases. These three changes threaten to disturb the ecological system of the whole region. The loss of the forest cover is drying out the resource base of the poor who depend on the forests for their livings. This has also adversely affected the cycle of the monsoons and therefore the agricultural pattern and climate change is playing the role of threat accelerator. The melting of the Himalayan ice cover appears to adversely affecting the water systems of South Asia and the availability of fresh water in the water-stressed region. Studies estimate that many of the rivers originating from the Himalayas would become dry by the first half of the twentyfifth century. The melting of the ice in the Himalayanregion will lead to a rise 
in the sea level potentially inundating all of the Maldives and nearly half of Bangladesh's paddy planting area.This paper argues, albeit military security issue between India-Pakistan-China is still relevant, that environmental security is one of the most prominent concerns of security studies in South Asia, therefore, the states need to attend to environmental problems to address the problematics of environmental security.

In the following sections of this paper, we revisit the critical debates of security studies to contextualize that environmental security is one of the most significant issues of contemporary security studies. Then we present the environmental problems of South Asia and its impacts upon issues of human security in the region. Next, we debate how environmental problems/security issues affect the national security of the states in South Asia followed by a conclusion.

\section{Critical Debate on Security: A Review}

The concept of security is highly contested as the concepts of democracy, power and justice. Wolfers(1962)pointed out that while the concept of (national) security is paramount, it is subjective and ambiguous in nature, and it may not have any precise meaning at all.According to Richard Ullmann(1983) the conception of traditional security is too narrow and military-oriented, as it does not give importance to basic human needs and resource scarcity. Ullmann(1983)argues that the redefinition of the conception of security is only possible through the change of mindset of civil society and policy makers. The debate of security steps forward in People, State and Fear(1983) a seminal book by Barry Buzan in which he argued that the concept of security is essentially contested. Buzan broadened the concept of security by presenting a list of five categories of security: military, political, economic, environmental, and social. Baldwin (1997) counters Buzan's concept of security as 'essentially contested' and posits that the concept of security is simply inadequately explicated. Baldwin (1997) agrees that security is subjective but specifies security in terms of 'security for whom', 'security of which values', 'how much security', 'from what threats', 'by what means', 'at what costs' and 'in what time period'.

Ken Booth (1991) argues that the referent object of security is individual and the concept of security should be understood in terms of 'emancipation' the freeing of people from all types of constraints including not just wars, but also issues of poverty, education and political oppression. Stephen Walt (1991) challenges that the attempt to expand the concept of security by including poverty, 
infectious diseases, and the environment runs the risks of over-broadening of the field, hampering intellectual coherence. In contrast, Jessica Matthew (1989) calls for redefining the concept of security by taking the environment seriously. Matthew contends that the environment deserves attention due to its potential for armed-conflict, worsening the conditions of human security. AmitavAcharya (1997) critiques that the prevailing security studies is predominantly Euro-centric which has entirely marginalized the Third World despite the fact that this is where the most conflicts of the world occur. Ole Wæver (1995)argues that the risk of securitization empowers policy-makers to dismiss the normal realm of policy discussion in the name of national security and enables them to mobilize all necessary resources in pursuit of their objectives. However, the creation of the concept of 'securitization' by policy-makers through the 'speech act' identifies and place issues within the category of security is political. In fact, Wæverpoints out that the de securitization of politics may help us to perceive certain types of public policy issues more clearly (Wæver 1995). Arguing for the necessity of the redefinition of the concept of security, Ullman $(1983,133)$ notes:

A more useful (although certainly not conventional) definition might be a threat to national security is an action or sequence of events that (1) threatens drastically and over a relatively brief span of time to degrade the quality of life for the inhabitants of a state, or (2) threatens significantly to narrow the range of policy choices available to the government of a state, or to private, nongovernmental entities... within the state.

Although Ullman's conception of security does not replace the historical definition of national security, it expands the traditional definition by including less direct, immediate, or intentional threats to a citizenry. Even though Ullman's formulation of security fails to capture the sense of basic urgency needed to induce citizens to pay for the costs of security, it nevertheless more accurately reflects citizens' actual security interests. The intellectual debate noted above demonstrates that security is very important not only for a state to survive but for all human beings to live and grow by capturing the issues of military security and human security.However, there is no agreement among academics, researchers and analysts as to how to define the concept of security.In the literature, security is defined as the freedom from threats, but there is no common understanding of what these threats are - threats could be different from individual to individual, 
state to state, continent to continent. Thus, it could be argued that the meaning of security is in fact in the definition of the definer. The military approach to national security is based on the concept that the threat to security arises only from other nations - interstate security threats due to anarchy - a purely realistic approach of international relations. The actual threat to anarchical security to nations is significantly reducing compared to the threats arising from intra-state problematic and environmental change. 'The military threat to national security is only one of many that governments must now address. The numerous new threats derive directly or indirectly from the rapidly changing relationship between humanity and the earth's natural systems and resources' (Brown 2015, 48). National security needs stable economy and resource base, as it cannot be isolated from individual security. Security is more than just being safe from the anarchical attack; it means the 'preservation of a system of civilization' not only the abstract concept of state(Huddle 1976).

Our Common Future (1987), a report prepared byThe World Commission on Environment and Development and commissioned by Gro Harlem Brundtland takes the view that environmental stress is both a cause and an effect of political tension and military conflict. The report argues that:

... a comprehensive approach to international and national security must transcend the traditional emphasis on military power and armed competition. The real sources of insecurity also encompass unsustainable development... Environmental stress can thus be an important part of the web of causality associated with any conflict and can in some cases be catalytic (Brundtland, 1987: 290-291).

The United States National Security Strategy $(2002,1)$ notes 'America is now threatened less by conquering states than we are by failing ones'. The NSS $(2015,12)$ emphasizes that 'Climate change is an urgent and growing threat to our national security, contributing to increased natural disasters, refugee flows, and conflicts over basic resources like food and water'. 'As environmental issues are an integral part of the basic needs of every human being an insecure and unhealthy environment is a mutual harm borne by all the societies living together in the same ecological region. Environmental depletion and the mutual dependence on shared resources can therefore be used as a connecting element between parties to conflict, regarding the improvement of the environmental situation as a common 
benefit to all the societies'(EcoPeace/Friends of the Earth Middle East, 2015, 296). The inability of poor and failing states' to address environmental change will exacerbate poverty and could destabilize national security of these weak states but also significantly affect the entire international state system.

\section{Environmental Problems in South Asia}

Non-traditional security (NTS) or human security issues have posed serious threats in South Asia. NTS issues primarily originate from nonmilitary sources such as climate change, resource scarcity, natural disasters, famine, drought, pollution, environmental degradation,human smuggling, drug trafficking, and organized transnational crime. While the traditional military power threatens the state, NTS threatens the survival and well being ofindividual, which has implications for the existentialism of the state and civilization. We recognize that each of NTS issues need serious considerations for the holistic security approach but we limit our focus on environmental security in South Asia in this paper.

Environmental security issues are pervasive in South Asia.Apart from entailing tremendous environmental degradation, the impact on regional security in South Asia due to environmental change is noticeable. Clearly, environmental security presents a long list of problems. They include the melting glaciers and rising sea levels, the illegal logging and devastation of the rainforests, the mismanaged urbanization and increasing pollution in air, water and soil, the changing climate due to anthropogenic emissions, and the extreme weather patterns and victorborne diseases to name a few from the list. These environmental issues do not stop at the psychologically drawn abstract Westphalian borders of the state rather theyare transnational problems.

South Asia is home to more than one-fifth of the total population of the world but also a region endowed with natural resources; however, the negative effects and risks of climate change have increased the vulnerability of the region. It is not only known to be the most disaster-prone region but also the most densely populated geographical region in the world where the majority of world's poor and vulnerable are to be found (Lal et al., 2011; UNEP, 2003). Taking notice of such emerging concerns the South Asian Association for Regional Cooperation (SAARC) has started taking steps to towards environmental concerns of the region. The publication South Asia Environmental Outlook 2009 (SAEO) by SAARCprovides a useful account of the state of the environment in South Asia and the challenges faced as well as the various initiatives being pursued to 
protect, preserve, and manage the diverse and fragile ecosystems of the region. The SAEO 2009 covers the state and trends of the environment emphasizing five key issues: climate change, food security, water security, energy security, and managing urbanization. The report highlights that South Asia is very vulnerable to climate change and that the impacts of climatechange have been observed in the form of glacier retreat in the Himalayan region. These glaciers form a unique reservoir that supports rivers including the Indus, Ganges, and Brahmaputra, which, in turn, are the lifeline of millions of people in South Asian countries, and climate change resulting in the glacier retreat exacerbates the challenges of poverty reduction, irrigation, food security, access to safe drinking water, and environmental sustainability, which are highly relevant to the MDGs and economic performances of South Asian countries and the lives of millions of the poor.

\section{Environmental Problems as National Security}

The most pessimistic observations are reverberated in Robert Kaplan's claims that environmental degradation would be 'the national security issue of the early twenty-first century' (Kaplan 1994, 58). Kaplan $(1994,58)$ contended that:

It is time to understand "the environment" for what it is: the national security issue... The political and strategic impact of surging populations, spreading disease, deforestation and soil erosion, water depletion, air pollution and possibly, rising sea levels in critical, over-crowded regions like the Nile Delta and Bangladesh - developments that will prompt mass migrations and, in turn, incite group conflicts-will be the core foreign policy challenge form which most others will ultimately emanate.

Another group of researchers, with implications on causes of war and conflict, studies the conditions under which environmental degradation may lead to violent conflict between and within nations (Homer-Dixon 1994, 1999). Homer-Dixon argued:

environmental scarcities are already contributing to violent conflicts in many parts of the developing world. These conflicts are probably the early signs of an upsurge of violence in coming decades that will be induced or aggravated by scarcity... Poor societies will be particularly 
affected since they are less able to buffer themselves from environmental scarcities and social crises they cause. These societies are, in fact, already suffering acute hardship from shortages of water, forests, and especially fertile land (Homer-Dixon 1994, 6).

In 2007, Norwegian Nobel Committee, awarding the Nobel Peace Prize jointly to IPCC and former United States Vice President Al Gore, noted that climate change was a threat to the security of mankind that could also 'induce large-scale migration and lead to greater competition for earth resources. Such changes will place particularly heavy burdens on the world's most vulnerable countries' and 'increase danger of violent conflicts and wars within and between states'(Norwegian Nobel Committee 2007). The London based International Institute for Strategic Studies, which asserts it to be the world's prominent authority on military-political conflict, identify climate change as a potential existential threat argued:

The impact of climate change has to be taken into account in almost every field of policy, on both the national and international level. Discussion of the threat it poses has tended to be from an environmental and humansecurity perspective. But the security dimension will come increasingly to the forefront as countries begin to see falls in available resources and economic vitality, increased stress on their armed forces, greater instability in regions of strategic import, increases in ethnic rivalries, and a widening gap between rich and poor. Climate change is at the heart of both national and collective security (International Institute for Strategic Studies, 2007, 68).

Climate scientists have predicted that looming environmental catastrophes have lingered over Bangladesh for decades. Many predictions of the small, densely populated, impoverished nation's fate have involved Malthus' famous theory, which posits that exponential population growth will outstrip linear increases in crop yields, provoking mass hunger and social breakdown. So far, Bangladesh has proven neo-Malthusian doomsayers wrong. Poverty and malnutrition are in decline, and the nation of 160 million population is self-sufficient in the production of rice and wheat, its staple foods. In Bangladesh, the risk does not seem to be overpopulation, but rather myriad adverse changes induced by rising temperatures and global changes. Bangladesh's geography makes environmental 
vulnerability inescapable, as it is a flat country surrounded on three sides by India and on the fourth by the Bay of Bengal. It's a delta, a massive drain for three mighty rivers that flow through the Indian subcontinent (the Ganges, Brahmaputra, and Meghna), for the Himalayan glacial melt, and for the area's annual monsoon rains(Yu, Alam, and Hassan 2010). The multiple risks of rising sea levels, droughts, and chaotic storms situate Bangladesh at number one on the global Climate Change Vulnerability Index. The impact may soon provoke the violent social breakdown long feared. Although annual flooding helps to restore the nutrient-rich soil on which the country's agricultural self-sufficiency depends, the waterlogged land loses 18-75 percent of its area to temporary flooding each year - which kills some 5,000 Bangladeshis annually and causes homelessness for many more, and disrupts the lives of the rural-dwelling majority. Rising waters will certainly mean losing habitable land and forcing people to migrate resulting into serious implications of human, national and international security.

The Maldives has a small population of about 320,000, having approximately 1192 islands. It has 197 inhibited islands. Tourism and fishery are two prominent revenue-generating industries in the Maldives. Its highest elevation of the land is just 1.5 meters above the sea level. Due to the impacts of climate change resulting into sea level rise, the loss of land and beach is continually occurring. Damage to coral reefs, water and food insecurity, damages to the existing infrastructures implicate the bourgeoning problems of the Maldives and the sustainability of its economy. Clearly, the Maldives is one of the most vulnerable countries to the impacts of climate change, which may affect human societies, settlement and natural ecosystems. If the projections of the sea level rise are correct, the national security of the Maldives is at risk because the country may disappear from the world map due to inundation. The gravity of climate change related risks is so significant, that at one point the government stated its intention to set-up a sovereign fund to relocate the local population of just over 300,000 people to Australia. According to United Nations Development Programme(2007; 2009) the main security risks, the Maldives is facing, includetsunamis, wind storms, heavy rainfall, storm surges, droughts, earthquakes and sea-level rise.

India has the second largest population in the world having increasing gap of income between rich and poor. Since 2011 India has been one of the largest energy consumer in the world after China, the United States, and Russia and its need for energycontinues to climb up as a result of the country's dynamic economic growthand modernization over the past several years (EIA, 2014). Its 
rapidlyaccelerating fossil fuel based economy is business as usual with itsimmense environmental costs. Although India has lately been one of the largest emitting countries in the world, the impacts of it are very high on its agricultural base and the people at the lowest rank of economic ladder. Changing weather patterns, concentrated rainfall, increasing frequency of droughts, depleting fresh water sources for drinking and irrigation purposes, pollution due to its high level of emissions are some of the examples of the risks of environmental change. Recent IPCC reports $(2007,2014)$ have shown that the most vulnerable sectors to climate change are water and agriculture, both of which are necessary for improving livelihoods. The melting of Himalayan glaciers will have a direct impact on the availability of water resources in India. Rainfall patterns will also be affected, resulting in disruptions to crop production and agricultural patterns - a sector that impacts the low-income groups the most. According to the European Parliament report (2008):

With an economy closely tied to its natural resources base and climatesensitive sectors such as agriculture, water, and forestry, India faces a major threat because of the projected changes in climate. India's large population primarily depends on climate-sensitive sectors like agriculture and forestry for livelihoods. The majority of the vulnerable population of India is poorly equipped to cope effectively with the adversities of climate change due to low capabilities, weak institutional mechanisms, and lack of access to adequate resources.

India has beenaspiring to be a great power but climate change is bringing crisis to its frontiers and putting pressures on its security. The first problem India is facing is water dispute with its immediate neighbours including China. Secondly, India could face a huge refugee influx from the world's seventh most populous country, Bangladesh. Thirdly, due to the impacts of climate change the economic and social disparities - already wide in Indian society - wouldintensify and probably threaten peace and security of the state (Chellaney, 2009).

Pakistan consists of 185 millions population, which is the second largest in South Asia and its $22.3 \%$ of the population suffers from abject poverty(World Bank, 2015). The country has a long latitudinal extent stretching from the Arabian Sea in thesouth to the Himalayan Mountains in north. It is located in sub-tropics and partiallyin temperate region. A larger portion of population is most vulnerable to 
climate change. Large numbers ofresidents live in low river deltas or coastal areas where sea level rise and floodingare the likeliest devastating consequences of rises in global temperatures as theclimate shifts(Farooqi, Khan, and Mir 2005).Climate change is affecting agriculture and livelihoods of the poor people in the country. Pakistan is particularly vulnerable to climate change because it has generally a warm climate. It lies in a geographical region where the temperature increases are expected to be higher than the global average with mostly arid and semi-arid land area. Its rivers are predominantly fed by the Hindu Kush-Karakoram Himalayan glaciers, which are reported to be receding rapidly due to global warming. Its economy is largely agrarian and highly climate sensitive. Pakistan is facing increasingly larger risks of variability in monsoon rains resulting into large floods and extended droughts. Under the influence of all these factors the water security, the flood security, the energy security and national security of the country are under serious threat(Ghulam et al. 2012).

The Kingdom of Bhutan has about 750 thousands population. Itis not only a landlocked countrybut has one of the mostformidable mountainous terrains in the world, ranging from 100 meters to 7,500 meters in height. The climatic conditions vary due to themountainous nature of the country.Bhutan's landscape ranges from subtropical plains in the south to the sub-alpine Himalayan heights in the north, where some peaks exceed 7,000 meters.From the existing development plans and vulnerability assessment report it is found that adverse effects of climate change includingvariability and natural disaster has a significant implication on theoverall development and national security of Bhutan. There are six most vulnerable areas to climate change. They include forests and biodiversity, agriculture, water resources, glacial lake outbursts, health,and landslides(Alam and Tshering, 2004). The economy of Bhutan, one of the world's smallest and least developed, is based on agriculture and forestry, which provide the main livelihoodfor more than $90 \%$ of the population(Alam and Tshering, 2004) but climate change has posed serious risk on agriculture, forestry and security of the country.

The Republic of Afghanistan is a landlocked country and the newest member of South Asian Association for Regional Cooperation. It has about 3.55 million of population. Approximately $80 \%$ of the population relies on the land for their livelihoods, a large proportion at subsistence level. According to United Nations Environmental Programme(UNEP, 2015), natural resources underpin the livelihoods of an estimated 70-80 percent of the population and many of these rural communities depend on agriculture, animal husbandry and artisanal mining 
for their daily survival. The country experienced a severe drought in 1998-2006 and more recently in 2008-09, which led to significant losses of crops such as wheat, rice, maize and potato. Droughts and land degradation exacerbated by climate change could further destabilize Afghanistan. Climate change is predicted to cause an increase in mean annual temperatures in Afghanistan, together with a decrease in mean annual rainfall and an increase in the intensity of rainfalls. Afghanistan has suffered more than three decades of varying degrees of conflict, dramatically reducing its resilience to decreasing rainfalls, climatic changes and national security (RTCC, 2013). The ongoing security issues such as ideological conflicts, poverty and low incomes, lack of clean energy and dependency on solid fuel, wood, and agricultural residues and low literacy rates will be elevated by the compounded risks of environmental change.

Nepal is a landlocked country with its geography divided into three ecological belts: Mountainous, Hilly and Plain.The dramatic differences in elevation found in Nepal result in a variety of environment.Agriculture is the dominant profession and the major economy in Nepal. The World Bank (2011)cites agriculture as the principal source of food, income, and employment for the majority of the population.Particularly for the poorest in Nepal the World Bank(2011) notes, the growth in agriculture is crucial for reducingpoverty, and preliminary findings from the NationalLiving Standards Survey indicate that despite the Maoistinsurgency, the sector has made a significant contributionto poverty reduction. Agriculture has been a major contributorof Nepalese gross domestic product (GDP) and hascontributed 35 per cent of the total GDP although only21 per cent of the total land area is properly cultivated(Central Intelligence Agency 2010). The impacts of climate changes are multidimensional and intricately vicious as it affects biotic and abiotic factorssuch as food, water, energy,weather, land, soil environment, forest and biodiversity,labour availability, physical infrastructure, marketfunctions, knowledge, tradition, policy matters and othersocioeconomic aspects. The business-as-usual brown industry civilization is melting the Earth's third largest pool of glaciers of Himalayas and Tibetan plateau that nourished Nepal as well as South Asian civilization. The drying of headwater due to changed land use combined with climate change is also eroding the land's capacity to support life and livelihood and risks inducing migration of people with the potential to flash local and trans-border conflicts(Dahal, 2011). Global warming and pollution by carbon dioxide build up, are not only making the monsoon rains unpredictable but also affecting agriculture, health, human and national security(Pandey, 2012). 
Indeed, climate change is imposingsocial and economic effects on human security, social peace and national security(Pandey, 2015).

\section{Conclusion}

This paper has discussed the concerns of environmental security in South Asia. It explored different meanings of security to explain how environmental security is associated with national security of the states in the region. The paper considered three major factors of environmental security problems: how environmental change can affect human security; how environmental change can turn into violent conflict and;how the combined impact of these two variables affect the developmental concerns and national security of the individual state in South Asia. The paper found that climate change is severely affecting in agriculture, economy and livelihoods of the most vulnerable stakeholders as well as the whole South Asian region. The seven countries in the region suffer from environmental security threats such as water stress, glacial burst and snow melt, drought, change in monsoon period and patterns of precipitation including sea-level rise. These insecurities are strongly related with human security and they are emerging concerns of national security.

\section{Endnotes}

Alam, Mozaharul, and Dago Tshering. 2004. "Bhutan: Capacity Strengtening in the Least Developed Countries For Adaptation to Climate Change." Working Paper 2. Dhaka: Bangladesh Centre for advanced Studies.

Brown, Lester. 2015. "Redefining National Security.” In Green Planet Blues: Critical Perspectives on Global Environmental Politics, edited by Ken Conca and Geoffery D. Dabelko, Fifth, 46-52. Boulder, CO: Westview Press.

Buzan, Barry. 1983. People, States and Fear: The National Security Problem in International Relations. Sussex, Great Britain: Wheatsheaf Books Ltd.

Central Intelligence Agency. 2010. “The World Factbook.” www.cia.gov/library/ publications/ the-worldfactbook/geos/np.html.

Chellaney, Brahma. 2009. "Climate Risks to Indian National Security.” In Indian Climate Policy: Choice and Challenges, edited by David Michael and Amit Pandya, 25-29. Washington, D.C.: Stimson. http://www.stimson. org/images/uploads/research-pdfs/brahma.pdf. 
Dahal, Dev Raj. 2011. "Climate Change and Security in South Asia.” Spotligt. http:/www.spotlightnepal.com/News/Article/-Climate-Change-andSecurity-in-South-Asia-.

EcoPeace/Friends of the Earth Middle East. 2015. "Environmental Peacebuilding: The Good Water Neighbors Project." In Green Planet Blues: Critical Perspectives on Global Environmental Politics, edited by Ken Conca and Geoffery D. Dabelko, Fifth. Boulder, CO: Westview Press.

EIA. 2014. "India: Overview.” US: Energy Information Administration.

Farooqi, Anjum Bari, Azmat Hayat Khan, and Hazmat Mir. 2005. "Climate Change Perspective in Pakistan.” Pakistan Journal of Metreology 2 (3): 11-21.

Ghulam, Rasul, Muhammad Afzal, Maida Zahid, and Syed Bukhari. 2012. "Climate Change in Pakistan." Technical Report PMD-25/2012. Islamabad, Pakistan: Pakistan Metrological Department.

Homer-Dixon, Thomas. 1994. "Environmental Scarcities and Violent Conflict: Evidence from Cases." International Security 19 (1): 5-40.

Huddle, Franklin P. 1976. "The Evolving National Policy for Materials." Science 191 (4228): 654-59.

Kaplan, Robert. 1994. "The Coming Anarchy." The Atlantic Monthly 273: 44-77.

Matthew, Jessica T. 1989. "Redefining Security.” Foreign Affairs 68 (2): 162 77.

National Security Strategy. 2002. "The National Security Strategy of the United States.” Washington, D.C.: U.S. Government Printing. http://www. whitehouse.gov/nsc/nss.html.

_. 2015. "National Security Strategy of the United States." Washington, D.C.: U.S. Government Printing.

Norwegian Nobel Committee. 2007. “The Nobel Peace Prize 2007,” October 12. http://nobelprize.org/nobel_prizes/peace/laureates/2007/press.html.

Pandey, Chandra. 2012. "The Impact of Climate Change on Agriculture and Adaptation in Nepal" 4 (1): 13-23.

- 2015. "Climate Change in South Asia: Green Bridging between Nepal and India.” In Environmental Security in the Asia-Pacific, 95-126. New 
30 Journal of International Affairs Vol. 1, No. 1, 2016

York, USA: Palgrave.

RTCC. 2013. "Afghanistan Faces Twin Threats of War and Climate Change." RTCC, February 22. http://www.rtcc.org/2013/02/22/afghanistan-facestwin-threats-of-war-and-climate-change/.

Ullman, Richard. 1983. "Redefining Security.” International Security 8 (1): 129-53.

UNDP. 2007. "Detailed Island Risk Assessment in Maldives Part 1: Hazards and Physical Vulnerability.” Maldives: United Nations Development Programme.

_. 2009. "Detailed Island Risk Assessment in Maldives Part 1: Hazards and Physical Vulnerability.” Maldives: United Nations Development Programme.

UNEP. 2015. "Disasters and Conflicts: Field Activities Uni." Kenya:

United Nations Development Programme. Accessed July 31. http:// www.unep.org/disastersandconflicts/CountryOperations/Afghanistan/ ClimateChangeAdaptation/tabid/133225/Default.aspx.

Wæver, Ole. 1995. "Securitization and Desecuritization.” In On Security, edited by Ronnie D. Lipschutz, 46-86. New York: Columbia University Press.

Walt, Stephen M. 1991. "The Renaissance of Security Studies.” International Studies Quarterly 35 (2): 211-39.

Wolfers, Arnold. 1962. "National Security as an Ambiguous Symbol.” In Discord and Collaboration: Essays on International Politics, 147-65. Baltimore, MD: The Johns Hopkins University Press.

World Bank. 2011a. "Nepal: Priorities for Agriculture and Rural Development." http://go.worldbank.org/D9M3ORHVL0.

—. 2011b. "Nepal: Priorities for Agriculture and Rural Development." New York: World Bank.

_. 2015. "Pakistan: Overview.” New York: World Bank. http://data. worldbank.org/country/pakistan.

Yu, W, M Alam, and A Hassan. 2010. Climate Change Risks and Food Security in Bangladesh. Oxford: Earthscan. 